\title{
31. SEDIMENTARY STRATIGRAPHIC FRAMEWORK ALONG THE LINE ISLANDS, EQUATORIAL PACIFIC ${ }^{1}$
}

\author{
Harry E. Cook, University of California, Riverside, California ${ }^{2}$
}

\section{INTRODUCTION}

The sedimentary deposits cored along the Line Islands (Figure 1) provide an example of sediment types and illustrate how they evolve along a growing volcanic island chain from its inception on the sea floor to its maturity with fringing shallow water carbonate environments (Schlanger et al., 1974). The main objective of Leg 33 was to test the "hot spot" theory for the evolution of the island chain. This theory dictates that the islands systematically evolved through time by the subjacent oceanic plate migrating northward over a magmatic hot spot. By dating the age of the uppermost edifice basalt at several sites, this theory can be tested. Additionally, the overlying sedimentary facies provide a potential test. If a distinct widespread lithologic facies formed in response to such an evolving diachronous island chain, the age of this facies from site to site might reflect this motion and serve as evidence independently of basement ages.

The purposes of this chapter are to (1) briefly describe the main characteristics of the lithologic units along the Line Islands; (2) show how these units correlate between sites; (3) explain their relation to the chronostratigraphy; (4) illustrate how this stratigraphic framework ties in to that of the central equatorial Pacific; and (5) suggest how the stratigraphy can be used to analyze the hot spot theory. This discussion draws on data in the shipboard hole summary books to which all Leg 33 scientists contributed. Additional data come from Legs, 8, 9, and 17. Lithologic details of Leg 33 stratigraphy are contained in the site reports of this volume (Chapters 2-6).

\section{LITHOLOGY}

Sediments along the Line Islands range in age from Santonian to Quaternary and are as much as 1000 meters thick (Figure 2). The postvolcanic stratigraphy is divisible into five distinct lithologic units (Figure 3) whose lithologic and temporal characteristics are summarized in Figure 4. The apparently homotaxial pattern of these units, that is, their occurrence in the same stratigraphic sequence at Sites 315,316 , and provisionally at Site 165, led Leg 33 scientists to feel confident in their correlation of these units between sites (Figure 3).

\section{Unit 1 (Brown and White Cyclic Oozes)}

Unit 1 is a distinct sequence of cyclically bedded, brown, radiolarian-rich oozes and white, foraminifer-

'Publication authorized by the Director, U.S. Geological Survey.

${ }^{2}$ Present address, U.S. Geological Survey, Menlo Park, California. rich oozes that occur in 2 to $25 \mathrm{~cm}$ thick beds. This unit occurs as the uppermost unit at Sites 165, 315, and 316. It is provisionally correlated with the Cyclic Unit of the Clipperton Oceanic Formation, one of the most widespread units in the equatorial Pacific, which extends as far east as the East Pacific Rise (Cook, 1972, 1975). At Sites 315 and 316 it occupies a short time span in the Pliocene and Quaternary. At Site 165, however, these cyclic beds may be as old as upper Eocene.

\section{Unit 2 (Varicolored Oozes and Chalks)}

This unit can be recognized at Sites 315 and 316 and is characterized by its brilliant purple, green, blue, and white calcareous oozes that are interlaminated in 1 to 10 $\mathrm{mm}$ thick beds. These varicolored sediments are probably correlative with the Varicolored Unit of the Clipperton Oceanic Formation, which is lithologically the same and occupies the same stratigraphic position directly beneath cyclically bedded oozes of the Cyclic Unit. If this correlation is valid, it extends this unit about $1500 \mathrm{~km}$ west of its previously cored position at Site 72 (Tracey, 1971; Cook, 1972, 1975). In the Line Islands it spans the interval from Oligocene to Quaternary. As shown in Figure 4 it may be diachronous and occupy a younger time span at Site 316 than at Site 315.

\section{Unit 3 (Brown Chert and Limestone)}

This unit is distinct from the overlying varicolored sediments and is characterized by the presence of highly indurated brown chert layers interbedded with a complex series of limestones, clayey limestones, and micritic claystones. The nonchert beds occur typically with compacted fucoid burrow structures and/or soft-sediment deformation structures so-called phacoids (Voight, 1962).

These cherts and limestones can be lithologically correlated between Sites 165,315 , and 316 but, unlike the above two units, cannot be correlated to the east. In the central equatorial Pacific, at Sites 72 and 77, this time span is occupied by the nannofossil-rich chalks of the Marquesas Oceanic Formation and the underlying iron/manganese-rich Line Islands Oceanic Formation.

Like the overlying Varicolored Unit this chert and limestone unit is diachronous at least from Sites 315 to 316. At Site 316 the upper and lower boundaries of the unit are younger than at Site 315.

\section{Unit 4 (Green Volcaniclastics, Limestones, and Claystones)}

Unit 4 is one of the most distinctive units in the Line Islands and is distinguished from the other units by its overall green color, common graded and massively bedded volcaniclastic breccias and conglomerates, and abundant graded, foraminifer-rich limestones. These graded and massively bedded deposits are discussed by 


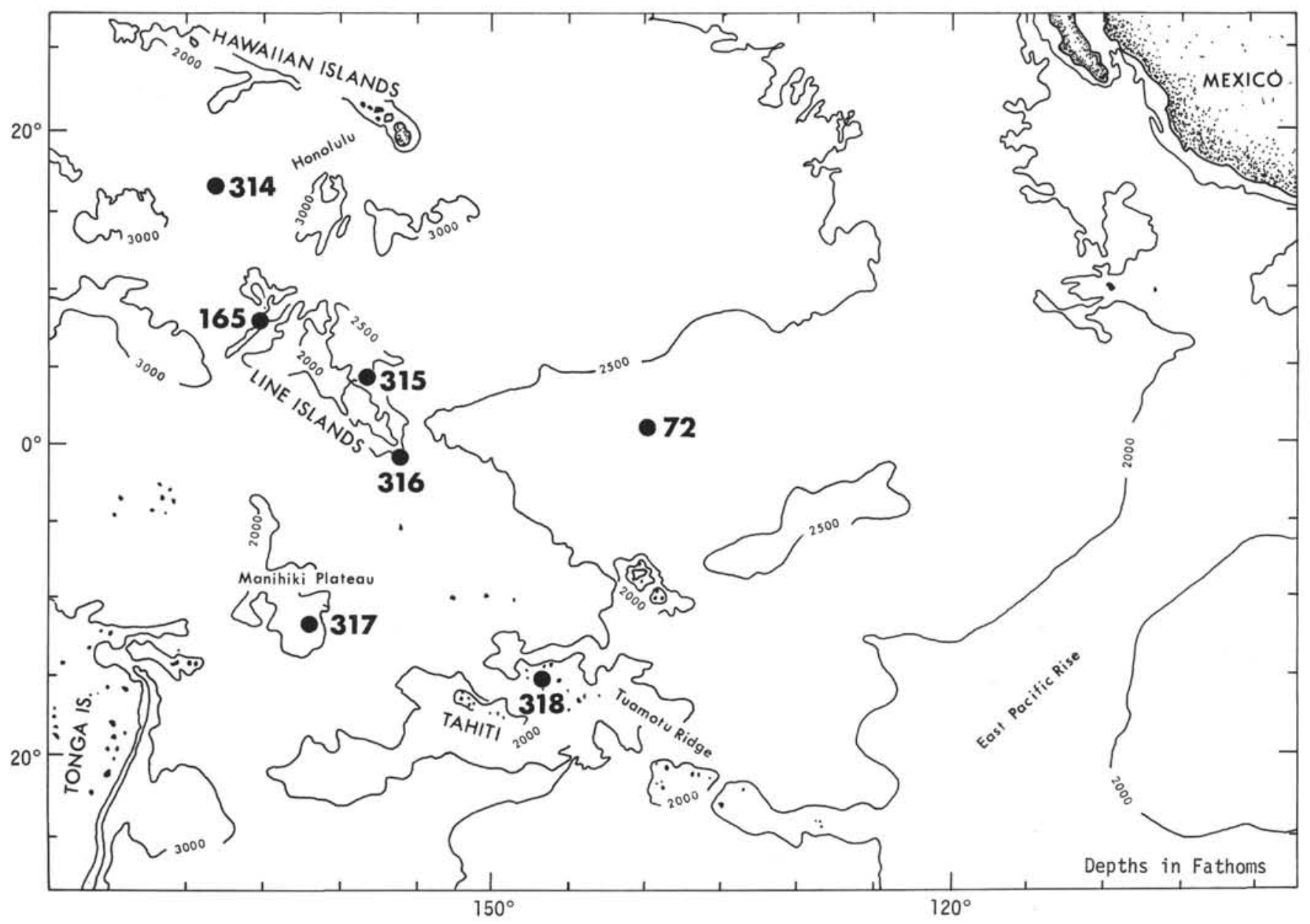

Figure 1. Location of sites drilled during Leg 33.

Cook, Jenkyns, and Kelts (this volume). Unit 4 is found at Sites 165,315 , and 316 , but does not extend eastward to Site 72 as do Units 1 and 2.

Deposition of these coarse-grained deposits terminated in the Campanian at Site 315, whereas at Sites 165 and 316 deposition continued into the Maestrichtian (Figure 4).

\section{Unit 5 (Reddish-Brown Ferruginous Claystones)}

This unit lies on and is interbedded with basaltic basement at Sites 165 and 315. Whether it is present at Site 316 is not known, as Site 316 was terminated in Unit 4 before basalt was reached. These claystones, discussed by Kelts and McKenzie (this volume), are characterized by their stratigraphic position directly on basalt, their reddish-brown color, and high clay content. They occupy a relatively short time span in the Cretaceous at both Sites 165 and 316 (Figure 4).

Their outward lithologic appearance and stratigraphic position on basalt is similar to that of the reddish-brown iron-rich Line Islands Oceanic Formation that occurs over a wide part of the equatorial Pacific (Cook, 1971, 1975).

\section{DISCUSSION}

As shown in Figure 3 the stratigraphic succession along the Line Islands is divisible into five lithologically distinct units that can be correlated between Sites 315 and 316 . Site 165 , which is $800 \mathrm{~km}$ northeast of Site 315 and which was drilled during Leg 17 (Winterer, Ewing, et al., 1973) has a very similar stratigraphic succession to that of Sites 315 and 316. Provisionally, there appears to be a good lithologic correlation with Sites 315 and 316 except for Unit 2, which is missing at Site 165. This may be due to a facies change, unconformity, or both. Units 1 and 2 are lithologically and stratigraphically correlative with the Cyclic Unit and the Varicolored Unit, respectively, of the Clipperton Oceanic Formation which is recognized over a wide part of the equatorial Pacific (Tracey, Sutton, et al., 1971; Cook, 1972, 1975).

When one compares the chronostratigraphic crosssection (Figure 2) of Sites 165, 315, and 316 with the lithostratigraphic cross-section (Figure 3), several interesting relationships emerge. At Sites 315 and 316 and perhaps 165 , the transition from chalks to limestones first occurs in Unit 3 but at significantly different subbottom depths (Figure 3). At Site 315 this change is at 800 meters, about 250 meters deeper than at Site 316, and is 500 meters deeper than at Site 165 . This transition, however, occurs at approximately the PaleoceneEocene boundary at all three sites.

At Site 316 the change from ooze to chalk occurs at about 270 meters. This lithification change coincides with an unconformity between the middle and upper 


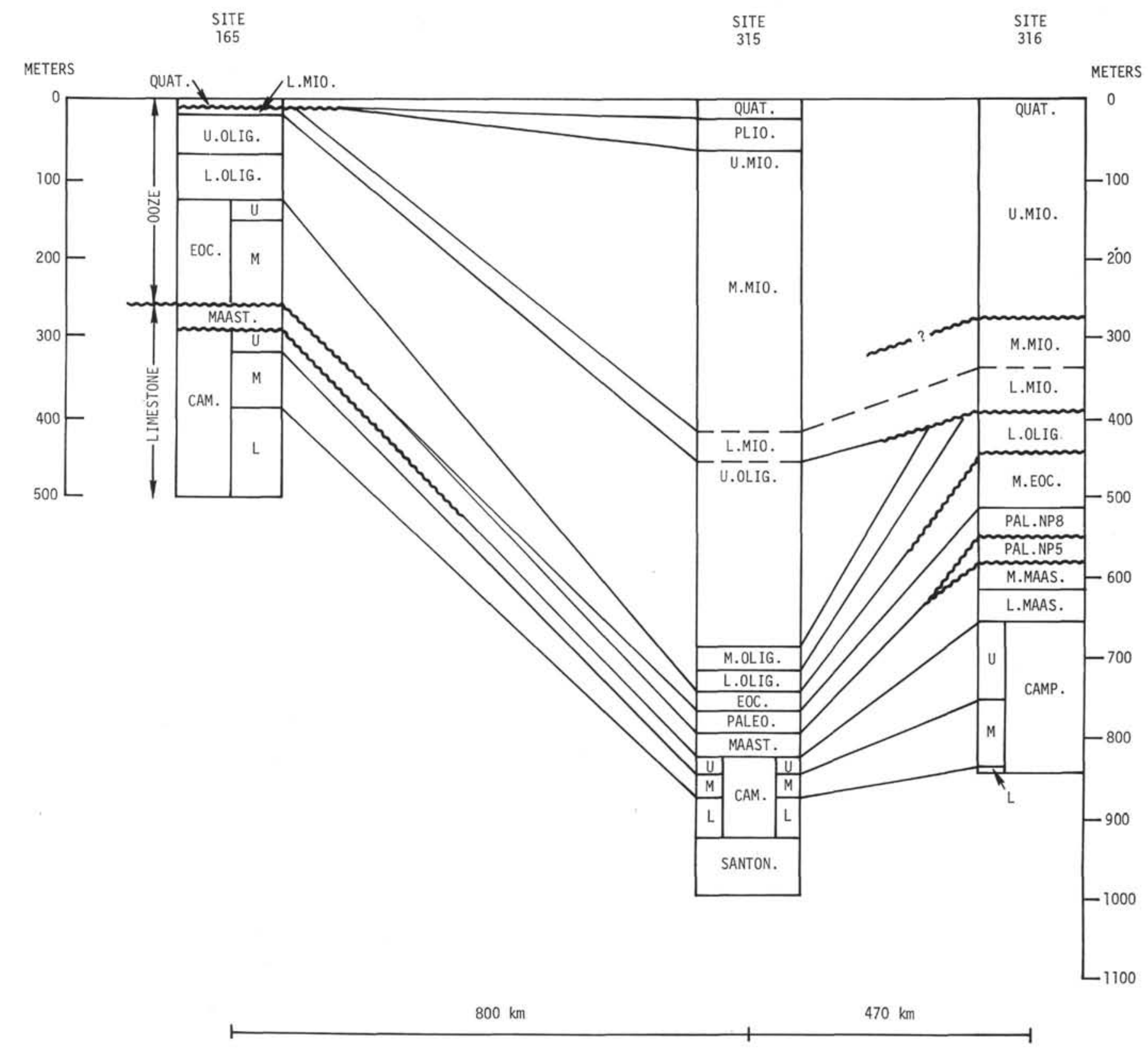

Figure 2. Chronostratigraphic framework along the Line Islands.

Miocene. At Site 315 this same lithification change occurs 100 meters deeper in the middle Miocene (Figure 2). Here, however, no unconformity was recognized. The independence of depth of burial and degree of chalkification has been noted previously (Winterer, Ewing, et al., 1971). More recently, Schlanger and Douglas (1974) have pointed out that the degree of cementation in the ooze-chalk-limestone transition depends more on initial sediment composition and time than on depth of burial.

If the Line Islands evolved in response to a plate slowly moving northward over a magmatic hot spot, one might expect the time span and age relationships of the lithologic units overlying edifice basalt to reflect this motion. The unit that under ideal circumstances might reproduce this motion would be Unit 4 which is com- prised of volcaniclastic gravity flows. This unit formed early in the evolution of the island chain presumably largely in response to the depositional slopes created by the submarine volcanism and derived its constituents from submarine eruptions which helped to initiate these flows. Thus, if a plate moved northward over a hot spot, volcaniclastic debris could begin to be shed basinward. As the plate continued to move northward this volcaniclastic unit in effect would become younger southward. Given the Pacific plate moving northward during a period of several tens of millions of years, Unit 4 could be expected to form a diachronous facies that becomes progressively younger to the south. In fact, if one looks only at Sites 315 and 316, the upper contact of Unit 4 does show a diachronous relationship becoming younger to the south from middle to late Campanian at 


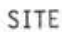

315
SITE

316

METERS

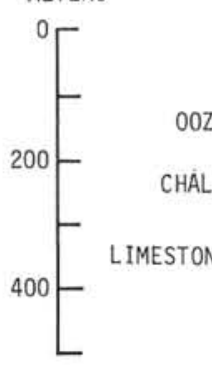

${ }^{0}\left[\begin{array}{c}\text { OOZE } \\ \text { CHALK } \\ \text { LIMESTONE }\end{array}\right.$

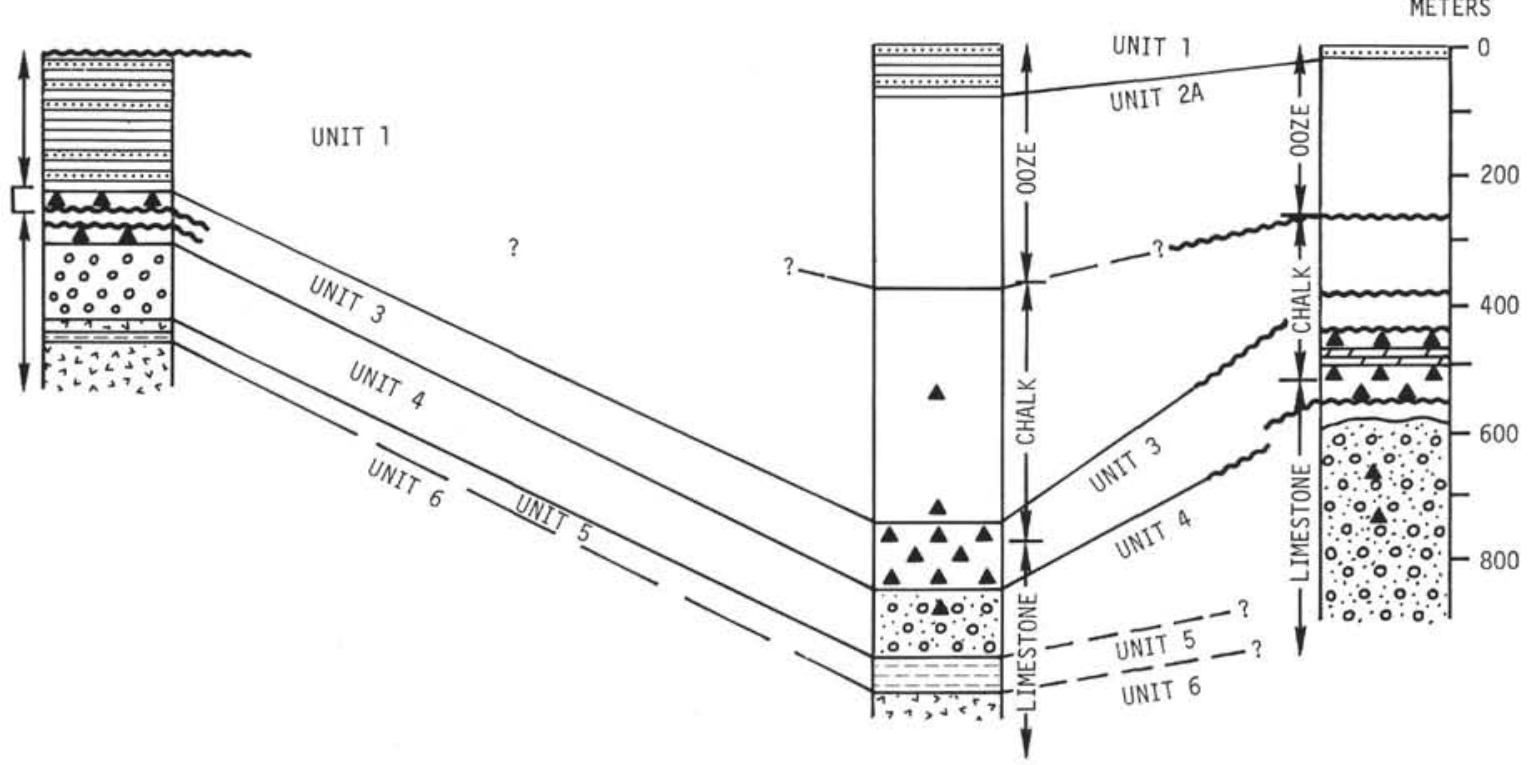

$800 \mathrm{~km}$

$470 \mathrm{~km}$

Figure 3. Rock stratigraphic framework along the Line Islands.

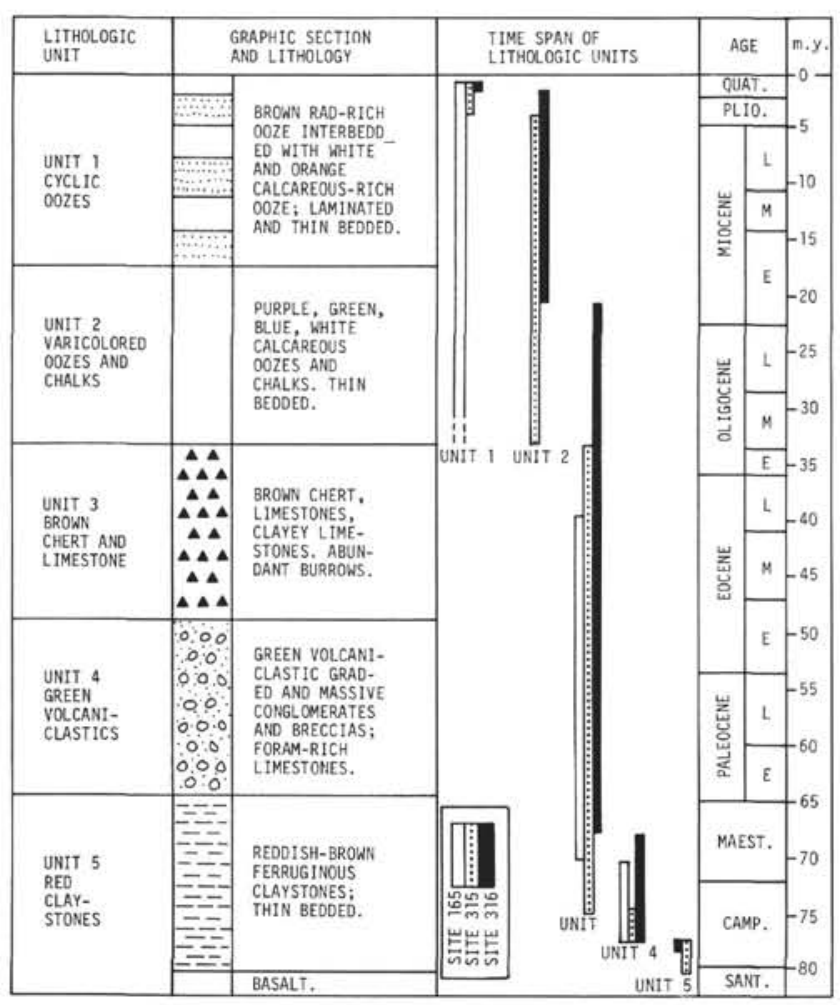

Figure 4. Composite stratigraphic section of the Line Islands lithologic units and their time span. The time span of each lithologic unit at each site is: Site 165 (cross-hachured); Site 315 (dotted); Site 316 (solid).
Site 315 to the middle Maestrichtian at Site 316. Using the time scale of Bukry (1974) this represents an age difference of about 5-8 m.y. A 5-8 m.y. age difference over a distance of about $470 \mathrm{~km}$ between Sites 315 and 316 amounts to a migration rate of $5-9 \mathrm{~cm} / \mathrm{yr}$. This could be taken as evidence to support the "hot spot" hypothesis; however, the age of the upper contact of Unit 4 at Site 165 is near the late Campanian to Maestrichtian boundary, younger than at Site 315. At best this tends to cast doubt on any possible trend between Sites 315 and 316. One could take an even more conservative view and say that given the normal variations in depositional patterns and the standard deviations inherent in relative and absolute age dating the age of Unit 4 is essentially the same along the Line Islands.

We are still faced with one curious relationship, however. Between Sites 315 and 316 lithologic Units 1 through 4 were deposited during a different time span that becomes younger southward (Figure 4). The hot spot theory aside, this may reflect some type of sedimentation control imposed by a northward moving Pacific plate.

In summary, one might suggest that the post-volcanic stratigraphic data do not prove or disprove the "hot spot" hypothesis.

\section{REFERENCES}

Bukry, D., 1974. Cretaceous and Paleogene coccolith stratigraphy, Deep Sea Drilling Project, Leg 26. In Davies, T.A., Luyendyk, B.P., et al., Initial Reports of the Deep Sea 
Drilling Project, Volume 26: Washington (U.S. Government Printing Office), p. 669-673.

Cook, H.E., 1971. Iron and manganese rich sediments overlying oceanic basaltic basement, equatorial Pacific, Leg 9, DSDP (abstract): Geol. Soc. Am. Ann. Mtg. Washington, D.C.

1972. North American stratigraphic principles as applied to deep sea sediments (abstract): Am. Assoc. Petrol. Geol. Bull., v. 56, p. 609-610.

1975. North American stratigraphic principles as applied to deep sea sediments: Am. Assoc. Petrol. Geol. Bull., v. 59, p. 817-837.

Schlanger, S.D. and Douglas, R.G., 1974. Pelagic ooze-chalklimestone transition and its implications for marine stratigraphy in pelagic sediments on land and under the sea. In Hsu, K.J. and Jenkyns, H.C. (Eds.), Spec. Pub. No. 1, Int. Assoc. Sed.: London (Blackwell).

Schlanger, S.D., Jackson, E.D., Boyce, R.E., Cook, H.E., Jenkyns, H., Johnson, D.A., Kaneps, A.G., Kelts, K.R.,
Martini, E., McNulty, C.L., and Winterer, E.L., 1974. Linear Island chain chronologies: Leg 33 deep sea drilling results from the Line and Tuamotu Islands (Abstract): Geol. Soc. Am. Abstract with Programs, v. 6, p. 941.

Tracey, J.I., 1971. Lithostratigraphy in pelagic sediments (abstract): Geol. Soc. Am. Abstract with Programs, v. 3, p. 734.

Tracey, J.I., Sutton, G.H., et al., 1971. Initial Reports of the Deep Sea Drilling Project, Volume 8: Washington (U.S. Government Printing Office).

Voight, E., 1962. Freuhdiagenetische deformation der turon en Planerckalke bei Halle/westf. als Folge einer Grossgleitung unter Bevuecksichtigung des phacoid-problems: Geol. Staats Inst. Hamburg, v. 31, p. 146.

Winterer, E.L., Ewing, J.I., et al., 1973. Initial Reports of the Deep Sea Drilling Project, Volume 17: Washington (U.S. Government Printing Office). 